Article

\title{
Ilmenite Alteration and Its Adsorption and Catalytic Reduction in U Enrichment in Sandstone-Hosted U Deposits from the Northern Ordos Basin, North China
}

\author{
Bo Ding ${ }^{1,2, *}$, Hong-Xu Liu ${ }^{2, *}$, Lin-Fei Qiu ${ }^{1,2}$, Chuang Zhang ${ }^{2}{ }^{\mathbb{D}}$ and De-Ru Xu ${ }^{1}$ \\ 1 State Key Laboratory Breeding of Nuclear Resource and Environment, East China University of Technology, \\ Nanchang 330013, China; qlf0602@163.com (L.-F.Q.); xuderu@gig.ac.cn (D.-R.X.) \\ 2 CNNC Key Laboratory of Uranium Resource Exploration and Evaluation Technology, China Beijing Research \\ Institute of Uranium Geology, Beijing 100029, China; zhangc198506@126.com \\ * Correspondence: 18773485100@163.com (B.D.); lhx100029@163.com (H.-X.L.); Tel.: +86-010-64960772 (B.D.); \\ +86-010-64954691 (H.-X.L.)
}

check for

updates

Citation: Ding, B.; Liu, H.-X.; Qiu, L.-F.; Zhang, C.; Xu, D.-R. Ilmenite Alteration and Its Adsorption and Catalytic Reduction in U Enrichment in Sandstone-Hosted U Deposits from the Northern Ordos Basin, North China. Minerals 2022, 12, 167. https://doi.org/10.3390/ $\min 12020167$

Academic Editors: Kunfeng Qiu and Georgia Pe-Piper

Received: 2 December 2021

Accepted: 25 January 2022

Published: 28 January 2022

Publisher's Note: MDPI stays neutral with regard to jurisdictional claims in published maps and institutional affiliations.

Copyright: (C) 2022 by the authors. Licensee MDPI, Basel, Switzerland. This article is an open access article distributed under the terms and conditions of the Creative Commons Attribution (CC BY) license (https:/ / creativecommons.org/licenses/by/ $4.0 /)$.

\begin{abstract}
Detrital ilmenite and its altered minerals are common in sandstone-hosted U deposits in the northern Ordos Basin, north China. Petrographic observation, SEM-EDS, EMPA, and LAMC-ICP-MS were utilized to characterize the spatial relationship between altered ilmenite and the $\mathrm{U}$ minerals, and to investigate the $\mathrm{U}$ enrichment mechanism and alteration processes of ilmenite. Ilmenite was completely or partially altered to leucoxene and anatase along its rim and crack in ore-bearing sandstone. Framboidal and cement pyrite of BSR and TSR origin were identified around altered ilmenite. Two U phases closely related to altered ilmenite contain Ti-coffinite (I) and coffinite (II). These data indicate that ilmenite alteration and the associated processes of $U$ enrichment can be divided into two stages. Stage one involves U pre-enrichment and adsorption, with stage two involving $\mathrm{U}$ enrichment via $\mathrm{TiO}_{2}$ (leucoxene and anatase) catalytic reduction. Ilmenite was altered into porous leucoxene that can adsorb $U$ as uraniferous leucoxene and Ti-coffinite (I) and framboidal pyrite directly by reactions with $\mathrm{H}_{2} \mathrm{~S}$, produced by sulfate-reducing bacteria during synsedimentary and early diagenesis stages. Altered ilmenite can enrich $U$ in the form of coffinite (II) through a catalytic reduction reaction which is triggered by $\beta$ and $\gamma$ radiation produced by previously adsorbed $\mathrm{U}$ during the uplift of ore-bearing bed in the Late Cretaceous period. In addition, cement pyrite can also reduce $\mathrm{U}^{6+}$ into $\mathrm{U}^{4+}$ which deposits on its surface in the form of coffinite (II). These results demonstrate a new mechanism, mediated by adsorption and catalytic reduction, to enrich $\mathrm{U}$ in sandstone-hosted U deposits.
\end{abstract}

Keywords: sandstone-hosted U deposits; altered ilmenite; colloidal pyrite; adsorption and catalytic reduction; Ordos Basin

\section{Introduction}

Oxidized Fe-Ti minerals have been widely reported in roll-type sandstone uranium (U) deposits located in south Texas, United States [1-6]. The replacement of detrital Fe-Ti oxides by iron disulfides is a common feature of these deposits, and Fe-Ti oxides and other Fe-rich detrital minerals of the host sandstone are a likely source of iron for pyrite [1-6]. The study of detrital Fe-Ti oxide minerals and their authigenic alteration products allows for the investigation of the geochemical conditions responsible for the U enrichment, which can provide insight into the development of the $U$ deposit [1-6]. This, in turn, provides a guide to facilitate further exploration. Iron disulfides can be formed by reactions between $\mathrm{H}_{2} \mathrm{~S}$ (derived from oil and gas) and Fe-Ti oxides. Moreover, $\mathrm{H}_{2} \mathrm{~S}$ and iron disulfides can reduce $\mathrm{U}^{6+}$ to $\mathrm{U}^{4+}$ and form $\mathrm{U}$ minerals [2,4]. Coffinite can also occur in these mineral deposits, with samples partly found in spatial association with a $\mathrm{TiO}_{2}$ mineral in Lower Old Red Sandstone sediments (Scotland) [7]. In this example, the U-Ti association is attributed 
to adsorption of $\mathrm{U}^{6+}$ by altered Ti-minerals prior to the growth of $\mathrm{U}^{4+}$ minerals. Later reports identified detrital ilmenite and its altered minerals widely in sandstone-hosted U deposits, particularly in central Asia. For example, at Dalmatov uranium deposit, Russia, nearly $30 \%$ of $U$ exists in the form of finely dispersed oxides $\left(\mathrm{U}^{4+}\right)$ or is chemically adsorbed by leucoxene $\left(\mathrm{U}^{6+}\right)[8]$. Some researchers have suggested that leucoxene formed by ilmenite alteration during the formation of sandstone-hosted $U$ deposits plays an important role in U enrichment through adsorption [8,9].

Recently, detrital ilmenite and its associated altered minerals have been widely identified in sandstone-hosted $U$ deposits and $U$ minerals in the basins of northern China. These include the Songliao [10,11], Erlian [12] and the Ordos basins [13-16], which have different geological characteristics in comparison to brannerite existing in sandstone-hosted U deposits identified by early geological surveys $[17,18]$. At present, domestic geological studies primarily focus on the spatial relationship between altered ilmenite and U minerals [10-14]. However, the $U$ enrichment mechanism of altered ilmenite and its specific role in the process of $U$ mineralization are still unclear, especially regarding the $U$ enrichment of altered ilmenite. Previous studies proposing this adsorption mechanism have been unable to adequately explain the presence of $U$ minerals located in the proximity of altered ilmenite [10-14], which indicates that the relationship between altered ilmenite and U minerals present may be related to reduction.

The Ordos Basin hosts important resources of coal, oil, natural gas and U. In China, it is referred to as "a basin of multiple-energy resources" [19-21]. In this study, sandstonehosted $U$ deposits located in the northern Ordos Basin of north China were selected to conduct investigations into the $U$ enrichment mechanism of altered ilmenite in sandstonetype $U$ deposits. The characteristics of ilmenite alteration and its spatial relationship with $U$ minerals were examined by petrographic observation, scanning electron microscopy (SEM), energy-dispersive $X$-ray spectrometry (EDS) and electron probe microanalysis (EPMA). In situ $S$ isotopes from pyrites related to altered ilmenite were obtained by laser ablationmulticollector inductively coupled plasma mass spectrometry (LA-MC-ICPMS), and the genesis of pyrite was discussed to provide clues for the alteration process of ilmenite. In combination with previous research results, the mechanism of $\mathrm{TiO}_{2}$ photocatalytic reduction was introduced and the $U$ enrichment mechanism of altered ilmenite and associated processes were discussed. The findings are significant in the context of mineralization mechanisms and the theory of sandstone-hosted U deposit genesis.

\section{Geological Setting}

The Ordos Basin is in the North China Craton, located between the Hercynian Inner Mongolia Daxinganling orogen to the north and the Indo-Sinian Qiliane Qinling orogen to the south (Figure 1a). It is bordered by the Alashan Block on the west and the Shanxi Block to the east (Figure 1a). The basin can be divided into six tectonic blocks [22,23], namely the Yiming uplift, Weibei uplift, Western rim thrust belt, Tianhuan depression, West Shaanxi flexure belt and the North Shaanxi incline [24] (Figure 1b). The Mesozoic-Cenozoic nonmarine Ordos Basin is thought to have developed on the Paleozoic North China platform with a basement of Archean and Proterozoic continental crust. The stratigraphy of the basin in the Paleozoic consists of Cambrian and Ordovician carbonates. Following this, the basin experienced a hiatus in regional deposition and underwent erosion from the Middle Ordovician to the Early Carboniferous, and was filled by the Upper CarboniferousPermian coal-bearing fluvial-deltaic clastic and minor shallow marine carbonates. The Triassic through Middle Jurassic strata consist of fluvial and lacustrine sandstones, shales, mudstones and coals. The Upper Jurassic strata are distributed on the western margin of the Ordos Basin and mainly consist of alluvial fan conglomerates $[25,26]$. 


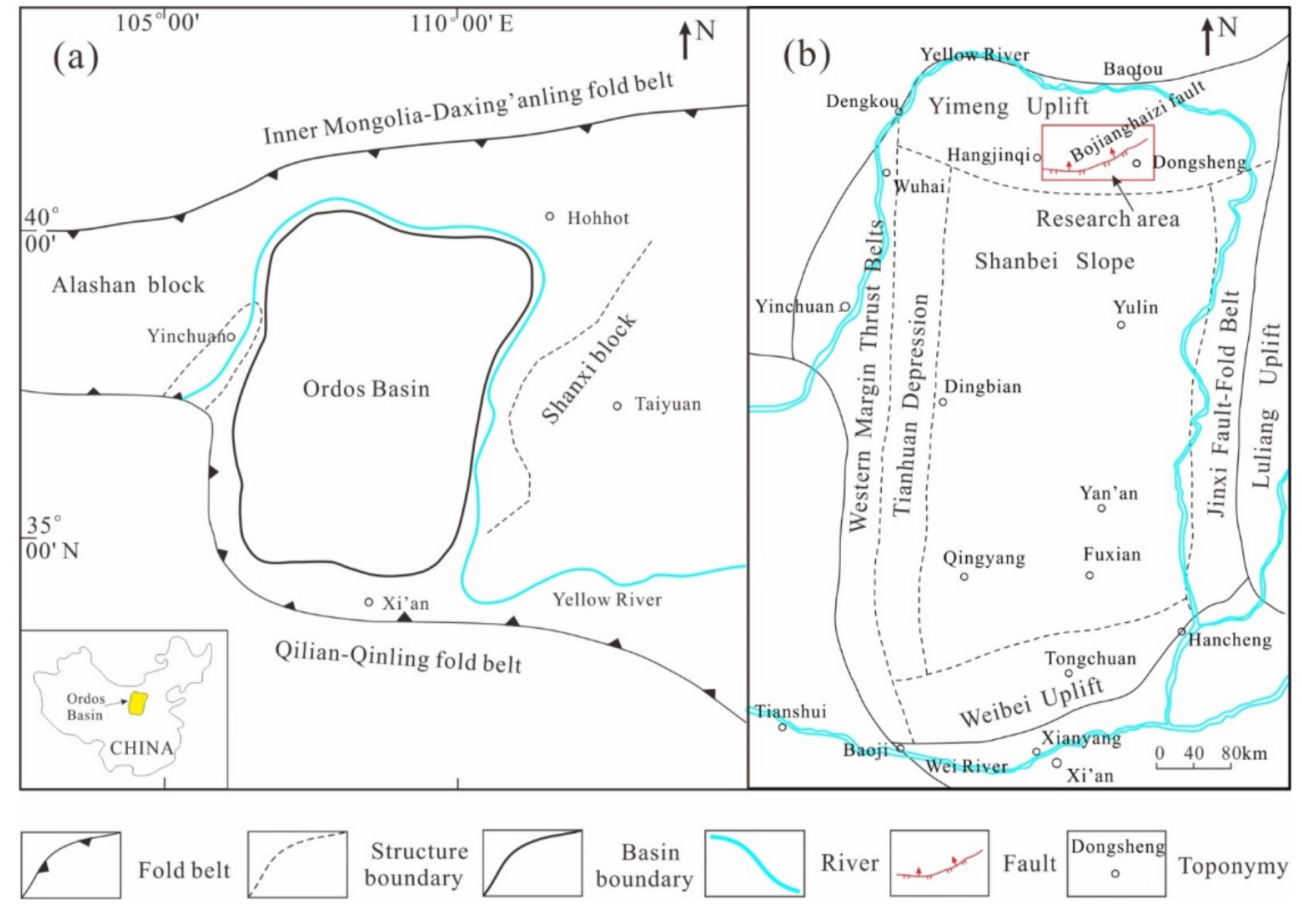

Figure 1. (a) Regional tectonic setting of the Ordos Basin; (b) Tectonic division map of Ordos Basin (modified after [20]).

The Ordos Basin is different from typical craton basins in that the margins were tectonically active, whereas the interior of the basin was relatively stable. The strata in the interior of the basin are generally horizontal or gently dip towards the center of the basin $\left(1 \sim 3^{\circ}\right)$. Those in the marginal parts were subjected to significant folding and faulting during Yanshanian (Jurassic and Cretaceous) orogeny [27,28]. Most areas of the basin experienced a short period of uplift and erosion during the Late Jurassic to the earliest Cretaceous period, and since the Late Cretaceous, the entire basin has been uplifted and formed a plateau [29-32]. In addition, studies conducted on vitrinite reflectance [28,31] and apatite fission $[29,32]$ indicate that the basin also experienced a thermal event in the Early Cretaceous. Early Cretaceous basalt outcrops located in the rim of the basin provide direct evidence for this thermal event [33].

\section{Sandstone-Hosted U Deposits in Northern Ordos Basin}

Sandstone-hosted U deposits in the northern Ordos Basin are primarily located in the Yimeng uplift. These include the Dongsheng, Nalinggou and Daying deposits which are developed successively from east to west $[34,35]$. The geology is controlled by the Bojianghaizi Fault, which plays an important role in the migration of hydrothermal and reducing gases, thereby providing the necessary reductant for the formation of $U$ minerals $[36,37]$ (Figure 2a).

The deposits are hosted within the Middle Jurassic Zhiluo Formation and are positioned at depths between 300 and $750 \mathrm{~m}$ below the surface. The Zhiluo Formation lies over the coal-bearing Yan'an Formation and underlies the Anding Formation (Figure 2b). The Anding Formation is entirely eroded in some areas, and the Lower Cretaceous directly overlies the Zhiluo Formation. The Zhiluo Formation can be divided into upper and lower members. The upper member is composed of purple to red mudstone, siltstone, sandstone and minor grayish green sandstone deposited in an arid meandering fluvial and lacustrine system. The lower member is primarily composed of gray or grayish green medium-tocoarse-grained sandstone with abundant carbonaceous debris, and was deposited in a humid or semihumid braided fluvial environment. The lower member also can be divided into two sections. The lower and upper sections are geologically similar, but are separated 
by a layer of massive mudstone that is several meters thick. The upper and lower sections are $40-150$ and 60-150 m thick, respectively, and consist of grey, grey-green, or grey-white braided stream facies and medium-to-coarse-grained sandstones containing carbonaceous debris and absorbed petroleum $[38,39]$.

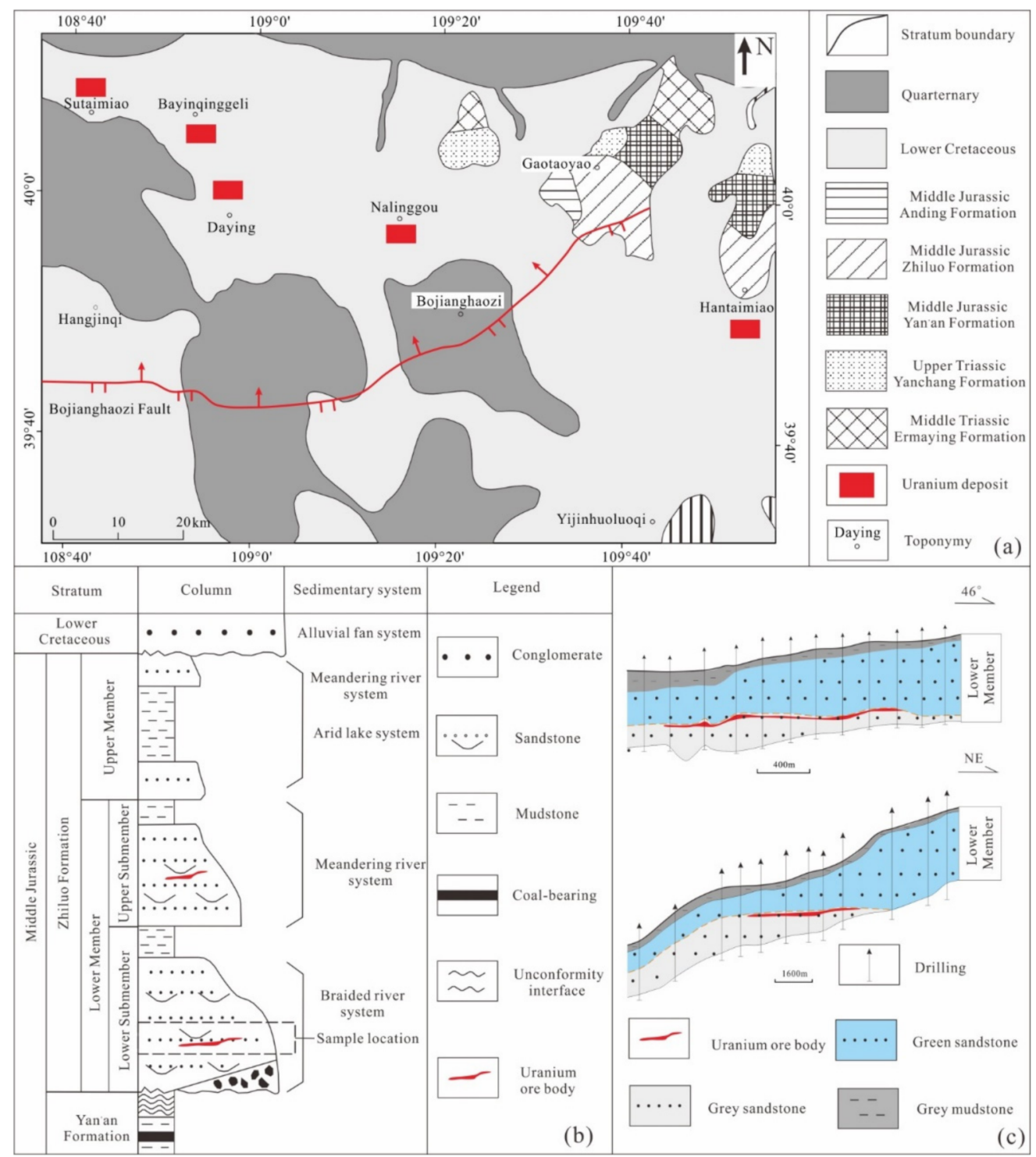

Figure 2. (a) Geological map of the northern Ordos Basin, showing the locations of the Bayinqinggeli, Daying and Nalinggou deposits (modified after [34]); (b) Ore-bearing column of the uranium deposit in the northern Ordos Basin (modified after [35]); (c) Cross-section showing tabular ore bodies in the Nalinggou U deposit (modified after [35]).

The $\mathrm{U}$ mineralization is preferentially hosted within redox zones consisting of a greento-greyish altered transition zone within fine-to-coarse-grained sandstones that contain abundant carbonaceous debris and sulfide minerals $[13,34,35,38]$. $U$ is generally present as coffinite and pitchblende, and shows a close association with carbonaceous debris and pyrite $[13,34,35]$. Comparatively little of these $U$ minerals are adsorbed onto clay minerals. $\mathrm{U}$ ore bodies are mainly produced in tabular morphologies, with a small amount of roll-type, which are controlled by the boundary between green and gray sandstone vertically and mainly produced as the gray sandstone located near the boundary $[34,35,38,39]$. Previous studies have shown that $U$ mineralization of sandstone-hosted $U$ deposits in the northern Ordos Basin mainly includes a pre-enrichment and a paleo-interlayer oxi- 
dation stage [34,35,38-41]. The pre-enrichment stage occurred during deposition or early diagenesis of the ore-bearing layer and the paleo-interlayer oxidation was formed in the late Cretaceous

\section{Sampling, Analytical Procedures and Methods}

The samples $(n=10)$ used in the present study were $U$ ores $(U$ content $>100 \mu \mathrm{g} / \mathrm{g}$ ) collected from the upper and lower parts of Zhiluo Formation of the Nalinggou deposit in the northern Ordos Basin (Figure 2b). A total of 20 polished sections were examined over the course of this study. Initially, detrital ilmenite and its altered mineral components were encircled during examination with an optical microscope (transmitted and reflected light). Following this, gold-coated blocks of the sandstone samples were examined with scanning electron microscopy (ETMA1600) equipped with an energy-dispersive X-ray spectrometer in order to identify the spatial distribution between altered ilmenite and $U$ minerals present.

Back-scattered scanning electron microscopy (ETMA1600) was conducted with an electronic probe (JXA-8100) in conjunction with an energy-dispersive X-ray spectrometer. This was carried out on the previously circled area at the Analysis and Test Center of the Beijing Research Institute of Uranium Geology. Analytical conditions were $15 \mathrm{kv}$ acceleration voltage, $20 \mathrm{nA}$ probe current, 1-5 $\mu \mathrm{m}$ beam diameter, 10, 20 and $40 \mathrm{~s}$ counting time for major, minor and trace elements, respectively. The primary aim of the analysis was to determine the alteration characteristics of ilmenite and the spatial distribution with uranium minerals present. The test implementation standard is GB/T15074-2008. The standard samples of $\mathrm{Si}, \mathrm{Na}$ and $\mathrm{Al}$ are albite, and the standard samples of $\mathrm{K}, \mathrm{Ca}, \mathrm{Mn}, \mathrm{Ti}, \mathrm{Fe}$, $\mathrm{Mg}$ and $\mathrm{U}$ are potassium feldspar, calcium rotaxane, rotaxane, rutile, hematite, pyroxene and metallic uranium. In addition, in situ S-isotope analysis of colloidal pyrite associated with altered ilmenite was performed at Wuhan Shangpu Analysis Technology Co., Ltd. (Wuhan, China), using a Resolution S-155, Nu Plassma II laser ablation-multicollector inductively coupled plasma mass spectrometry (LA-ICP-MS). The analytical conditions consisted of a $266 \mathrm{~nm}$ output wavelength, 10-20 $\mu \mathrm{m}$ laser spot size, and $2 \mathrm{~Hz}$ pulse repetition frequency with argon and helium used as the carrier gases. Each individual analysis consisted of background collection for $25 \mathrm{~s}$, sample signal acquisition for $50 \mathrm{~s}$ and a wash time of $40 \mathrm{~s}$. Isotopic values were calculated using the following equation [42,43].

$$
\delta^{34} S \%=1000\left({ }^{34} S /{ }^{32} S_{\text {unk }} /{ }^{34} S /{ }^{32} S_{V C D T}\right)
$$

where ${ }^{34} S /{ }^{32} S_{u n k}$ is the ${ }^{34} S /{ }^{32} S$ ratio from the unknown sample, and ${ }^{34} S /{ }^{32} S_{V C D T}$ is the ${ }^{34} S /{ }^{32} S$ ratio for the international standard Vienna Canyon Diablo Troilite (VCDT).

\section{Results}

\subsection{Characteristics of Ilmenite Alteration}

SEM-EDS and EMPA analyses demonstrate that detrital ilmenite is prevalent in the Nalinggou $U$ deposit and exhibits different degrees of alteration along the rim and crack (Figures 3-5). Ilmenite was altered, causing the rim to become rounded and the interior dirty. Leucoxene, a mixture of cryptocrystalline $\mathrm{TiO}_{2}$ and hematite, was identified in proximity to ilmenite and has the characteristics of porous structure (Figures 3d,e, 4a and 5). Moreover, anatase particles were also observed around ilmenite (Figures 3a-c and 4). They are very small $(10 \sim 30 \mu \mathrm{m} \times 30 \sim 50 \mu \mathrm{m})$ and most of them are in plate shape (Figure $3 \mathrm{~b}$ ). Some ilmenites were completely altered into and replaced by porous leucoxene or anatase crystal clusters (Figures $3 \mathrm{a}$ and $4 \mathrm{c}$ ). Others were partially altered with minor amounts of residual ilmenite, and the exterior comprised porous leucoxene or anatase crystal clusters (Figures $3 c, 4 a, b$ and 5). EMPA surface analysis demonstrated that the Fe content gradually decreased to zero from the core to the rim, with the proportion of Ti gradually increasing (Figure 4). In addition, pyrites were also seen to be closely associated with altered ilmenite (Figures $3 e, f$ and 5) and its morphologies were classified as framboidal and cement. Cement pyrite occurs primarily as a matrix-forming mineral in the host sandstone and is the most abundant type of pyrite (Figure 5). It comprised several pyrites with subhedral to 
euhedral structures which were often around the earlier framboidal pyrite and altered ilmenite (Figures $3 e$ and 5). Individual framboids, which generally range in diameter from 2 to $20 \mu \mathrm{m}$, mostly comprise a large number of pyritohedral or octahedral microcrystals $(<1 \mu \mathrm{m})$ in an ordered array (Figure 3f), and often gather together to form polyframboidals (Figures $3 \mathrm{f}$ and $5 \mathrm{~b}, \mathrm{~d}, \mathrm{f})$.
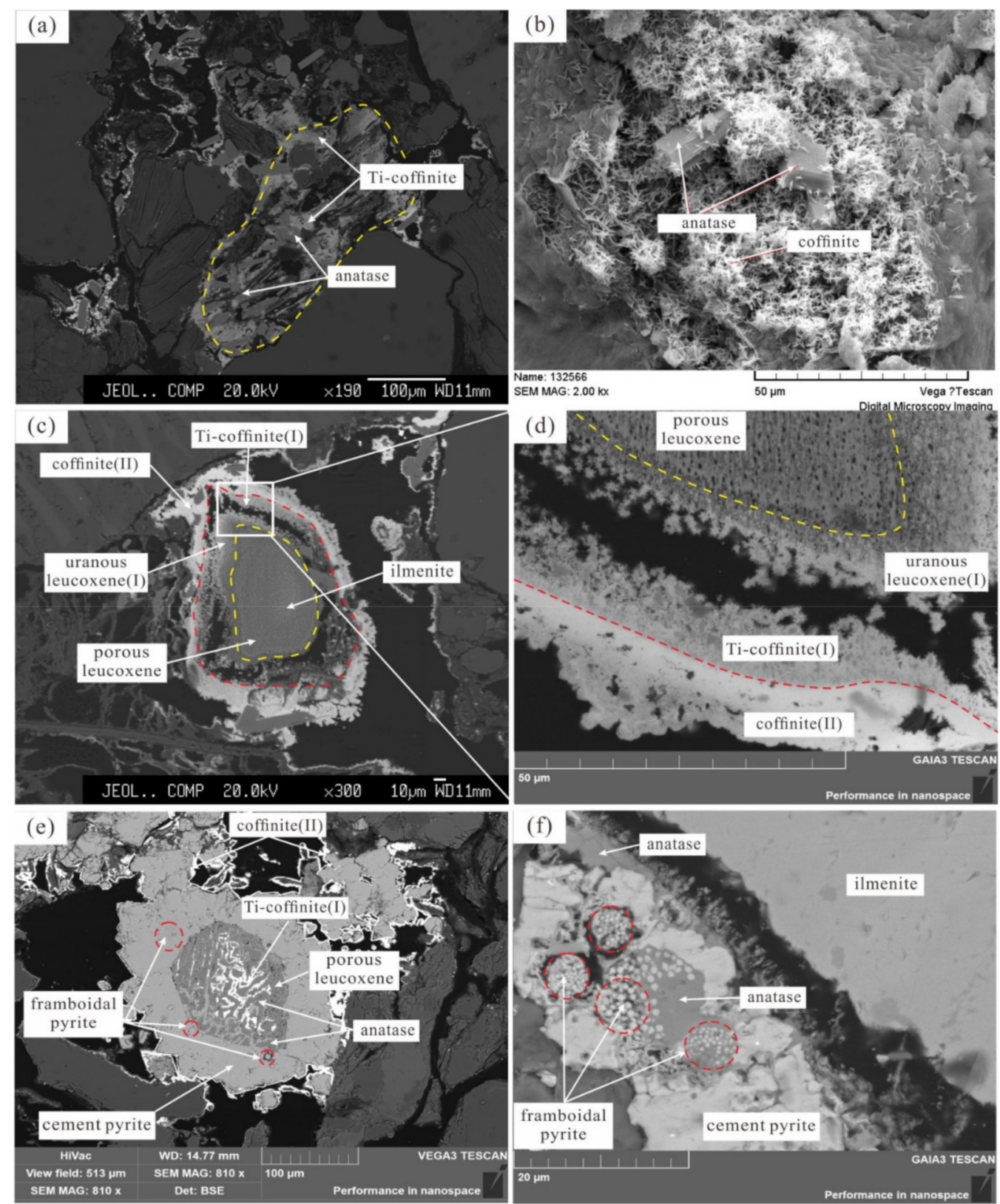

Figure 3. Alteration characteristics of altered ilmenite and its relationship with $U$ minerals in sandstone-hosted U deposits in the Nalinggou U deposit in the northern Ordos Basin. (a) Completely altered ilmenite replaced by anatases and Ti-coffinite (BSE). (b) Coffinite in the form of burrs and needles produced around anatase (SE). (c) Partially altered ilmenite with minor amounts of residual ilmenite and mineral assemblage sequence of ilmenite, porous leucoxene, uraniferous leucoxene, Ti-coffinite and coffinite (BSE). (d) Mineral assemblage sequence of porous leucoxene, uraniferous leucoxene, Ti-coffinite and coffinite (SE). (e) Partially altered ilmenite replaced by anatases, porous leucoxene and Ti-coffinite, and coated by cement pyrite and coffinite (SE). (f) Polyframboidal comprising some framboids and individual framboids comprising pyritohedral or octahedral microcrystals in an ordered array (SE). 

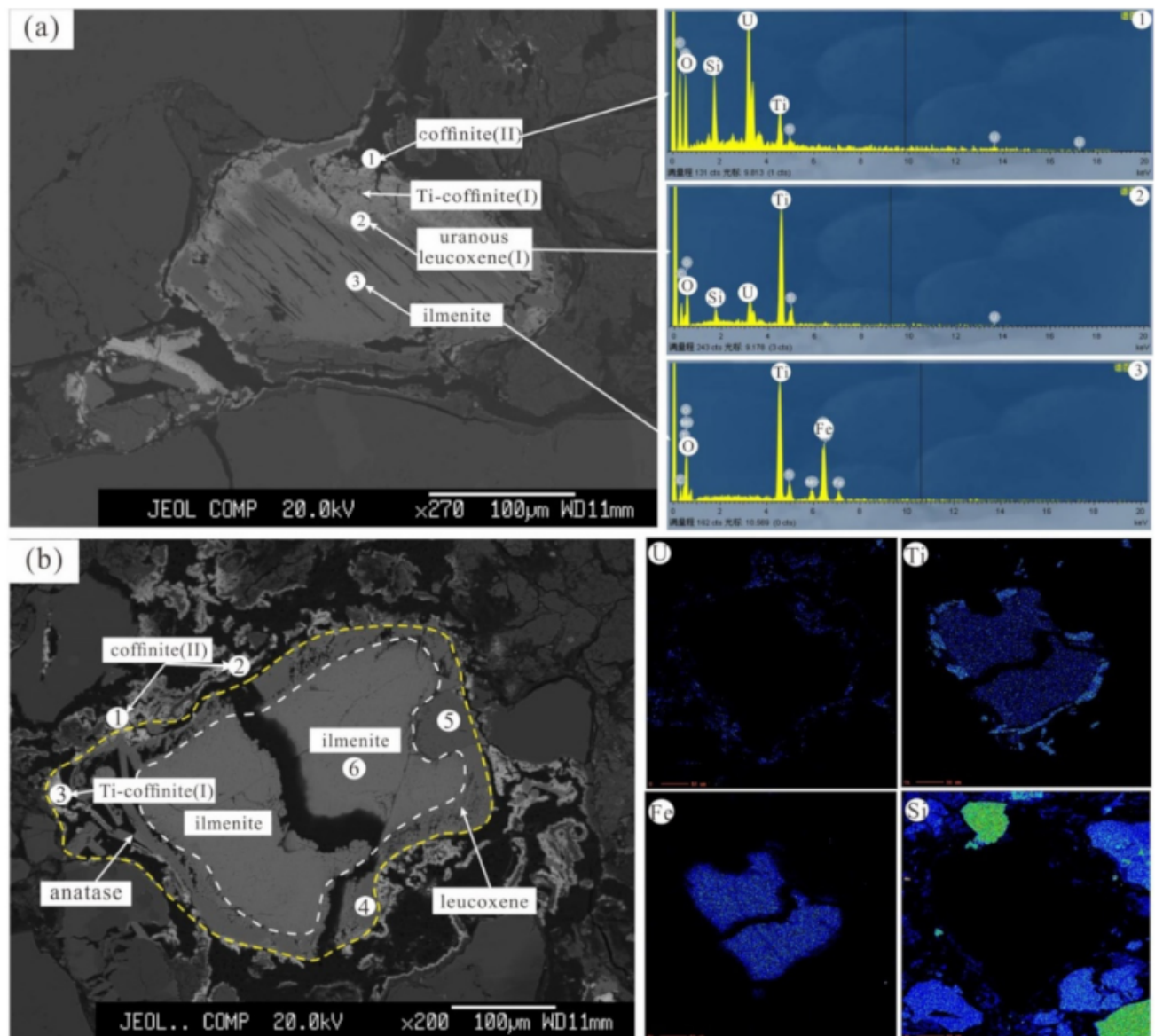

(c)
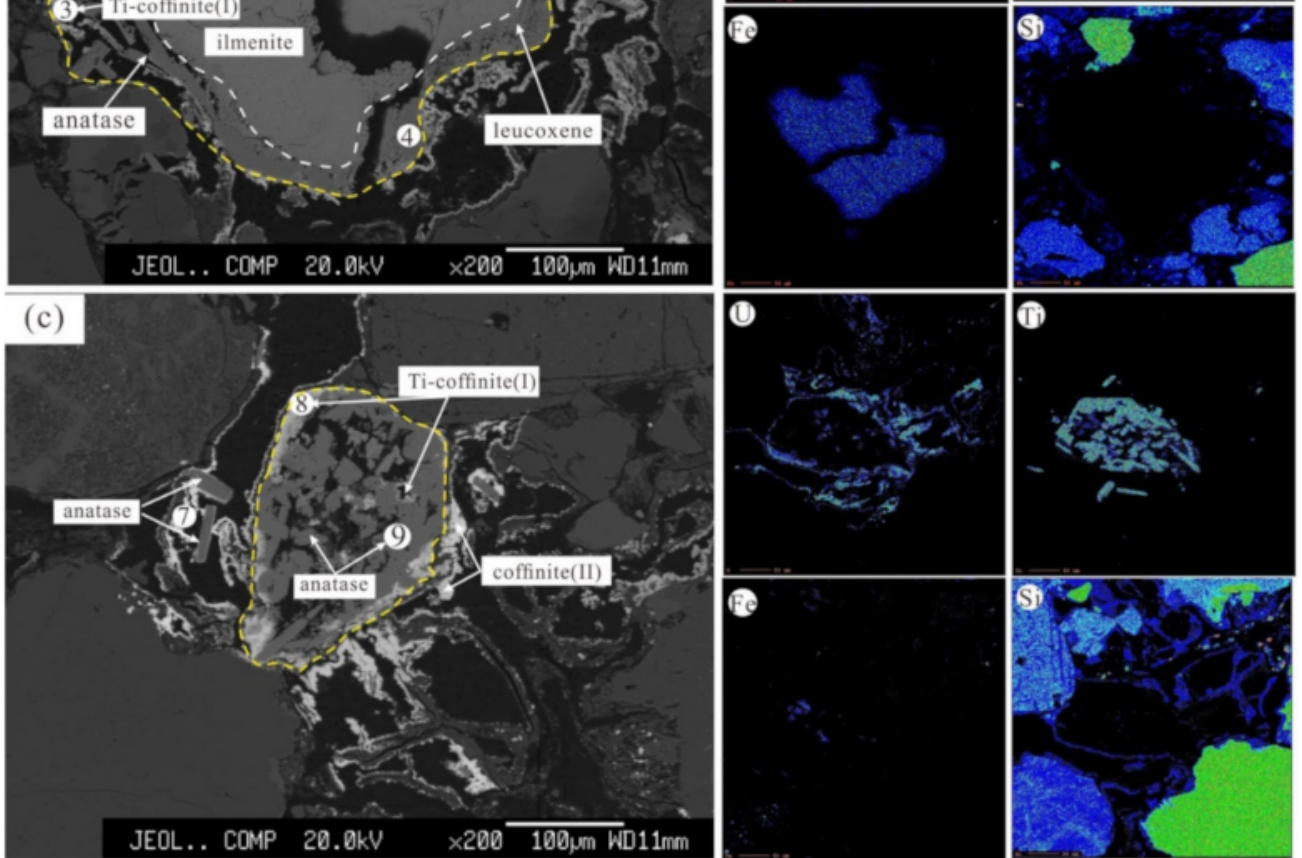

Figure 4. Geochemical characteristics of altered ilmenite and U minerals in sandstone-hosted U deposits in the Nalinggou $U$ deposit in the northern Ordos Basin. (a) Partially altered ilmenite with minor amounts of residual ilmenite and mineral assemblage sequence of ilmenite, porous leucoxene, uraniferous leucoxene, Ti-coffinite and coffinite (BSE). (b) Partially altered ilmenite with minor amounts of residual ilmenite and mineral assemblage sequence of ilmenite, porous leucoxene, anatase, Ti-coffinite and coffinite (BSE). (c) Completely altered ilmenite replaced by anatases, Ticoffinite and coated by coffinite (BSE). 

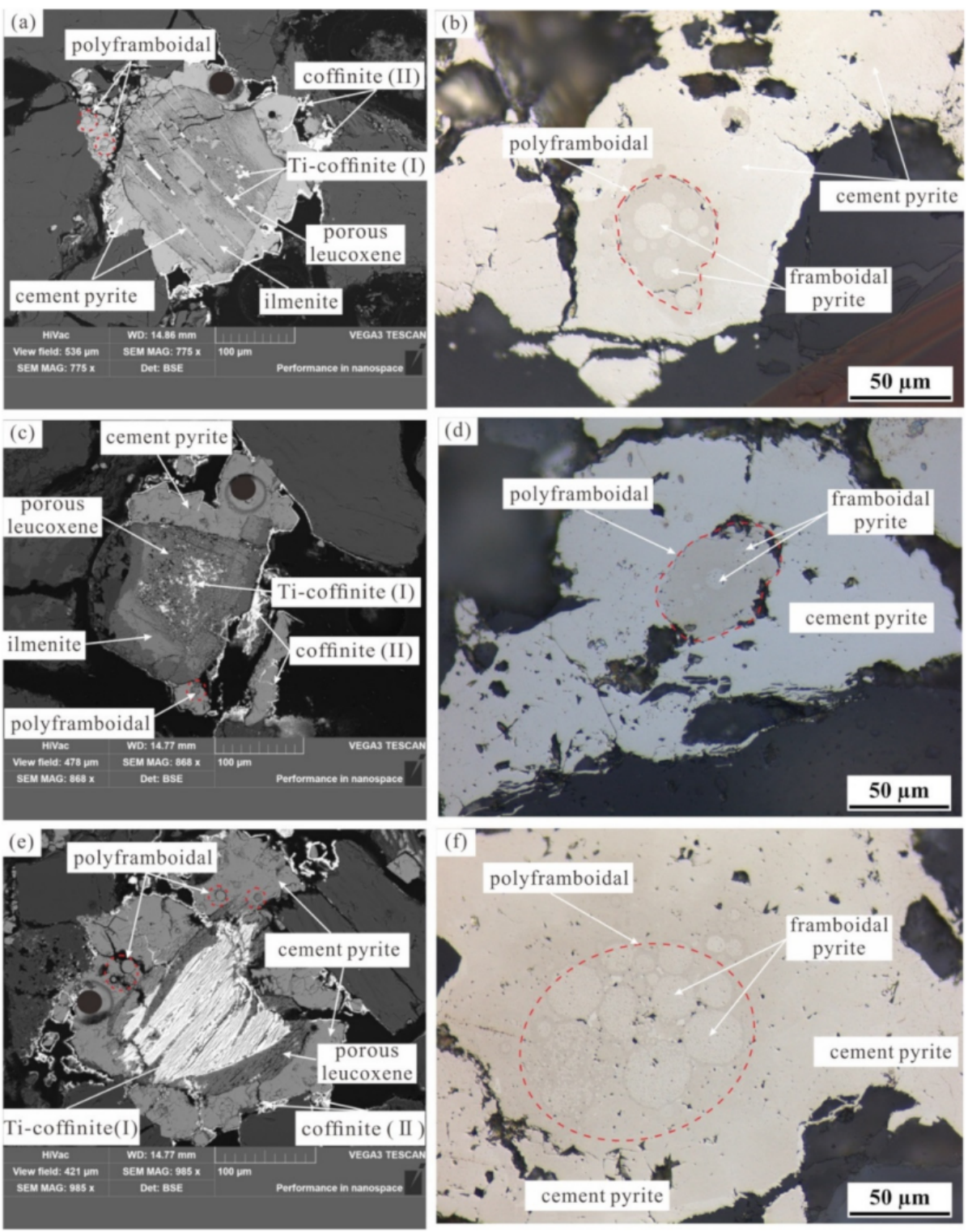

Figure 5. In situ sulfur isotopic composition characteristics of pyrite and its relationship with altered ilmenite and $U$ minerals in the Nalinggou $U$ deposit in the northern Ordos Basin. (a) Ti-coffinite produced in the pores of leucoxene and crack of altered ilmenite, coated by cement pyrite and coffinite (SE). (b) Polyframboidal pyrite comprising some framboids and coated by cement pyrite. (c) Ti-coffinite produced in the pores of leucoxene and coated by cement pyrite and coffinite (SE). (d) Polyframboidal pyrite comprising some framboids and coated by cement pyrite. (e) Ti-coffinite produced in the pores of leucoxene and coated by cement pyrite and coffinite (SE). (f) Polyframboidal pyrite comprising some framboids and coated by cement pyrite.

\subsection{Spatial Relationship between Altered Ilmenite and U Minerals}

In the northern Ordos Basin, $\mathrm{U}$ minerals are closely associated with altered ilmenite and often are identified around anatase or porous leucoxene. Some of them are produced in the pores and cracks of altered ilmenite (Figures 3d,e, 4 and 5a,c,e) and are closely related to leucoxene and anatase in the form of burrs and needles (Figure 3b,d); the others are produced around altered ilmenite or cement pyrite (Figures 3d,e, 4 and 5a,c,e). Moreover, EMPA analyses demonstrated that coffinite is the primary $\mathrm{U}$ mineral associated with altered ilmenite, with the $\mathrm{UO}_{2}$ content ranging from $46.71 \%$ to $70.38 \%, \mathrm{SiO}_{2}$ from $12.12 \%$ to $18.28 \%$ and $\mathrm{TiO}_{2}$ from $0.34 \%$ to $16.51 \%$ (Table 1 ). In addition, there is some uraniferous leucoxene produced around the altered ilmenite (Figures $3 \mathrm{c}$ and $4 \mathrm{a}$ ). Dependent on the occurrence and 
composition, coffinite can be divided into two phases. The first phase was Ti-coffinite (I), which has characteristically high $\mathrm{TiO}_{2}$ content and was seen to occur in cavities of altered ilmenite as knitted aggregates (Figures 3d,e, 4 and $5 \mathrm{a}, \mathrm{c}, \mathrm{e}$ ). Moreover, uraniferous leucoxene (I) also belongs to this phase. The second phase, coffinite (II), has lower $\mathrm{TiO}_{2}$ content and is seen in colloidal form in proximity to altered ilmenite (Figures $3 c, d$ and $4 b, c)$. SEM-EDS analysis and EMPA mapping of $\mathrm{Ti}, \mathrm{Fe}, \mathrm{U}$, and $\mathrm{Si}$ show that mineral assemblage sequences of ilmenite, leucoxene, uraniferous leucoxene (I) or Ti-coffinite (I) and coffinite (II) can be formed with partial alteration of ilmenite, and that mineral assemblage sequences of leucoxene or anatase, Ti-coffinite (I) and coffinite (II) can be formed with complete alteration (Figure 4). Notably, some altered ilmenites associated with Ti-coffinite (I) are coated by cement pyrite which was surrounded by coffinite (II) (Figures $3 \mathrm{f}$ and $5 \mathrm{~d}-\mathrm{f}$ ). This also indicates that the $\mathrm{U}$ mineralization related to altered ilmenite may exist in two stages.

Table 1. Data of electron probing analyses for $U$ minerals and the alteration product of ilmenite in sandstone-hosted U deposits in northern Ordos Basin.

\begin{tabular}{|c|c|c|c|c|c|c|c|c|c|c|c|c|c|c|c|c|c|}
\hline Spot & $\mathrm{SiO}_{2}$ & $\mathrm{UO}_{2}$ & $\mathrm{Na}_{2} \mathrm{O}$ & $\mathrm{CaO}$ & $\mathrm{MgO}$ & $\mathrm{K}_{2} \mathrm{O}$ & $\mathrm{Al}_{2} \mathrm{O}_{3}$ & $\mathrm{FeO}$ & $\mathrm{TiO}_{2}$ & $\mathrm{~V}_{2} \mathrm{O}_{3}$ & $\mathrm{MnO}$ & $\mathbf{P}_{2} \mathrm{O}_{5}$ & $\mathrm{Cr}_{2} \mathrm{O}_{3}$ & $\mathrm{SO}_{3}$ & $\mathrm{ThO}_{2}$ & Amounts & Mineral \\
\hline 1 & 17.04 & 49.05 & 0.25 & 1.53 & 0.86 & 0.23 & 2.97 & 1.03 & 0.34 & 0.43 & / & 0.17 & / & 0.10 & 0.08 & 74.08 & Coffinite (II) \\
\hline 2 & 15.92 & 48.27 & 0.13 & 1.19 & 0.17 & 0.25 & 1.28 & 0.37 & 1.09 & 0.30 & / & 0.09 & / & / & / & 69.06 & Coffinite (II) \\
\hline 3 & 18.22 & 66.33 & 0.11 & 1.93 & 0.06 & 0.22 & 1.33 & / & 5.30 & 0.38 & / & 0.32 & / & 0.05 & / & 94.25 & Ti-Coffinite (I) \\
\hline 4 & 0.30 & 0.32 & 0.06 & 0.09 & 0.06 & 0.02 & 0.08 & 0.73 & 96.17 & 1.38 & 0.04 & / & / & / & 0.07 & 99.32 & Anatase \\
\hline 5 & 0.91 & 0.13 & 0.15 & 0.20 & 1 & 0.04 & 0.29 & 0.87 & 95.49 & 1.20 & 0.07 & / & 0.07 & / & 1 & 99.42 & Anatase \\
\hline 6 & / & / & 0.19 & 0.02 & 0.62 & / & 0.02 & 45.71 & 51.58 & 0.53 & 0.50 & 0.05 & 0.20 & / & / & 99.42 & Anatase \\
\hline 7 & 18.28 & 70.32 & 0.15 & 2.21 & / & 0.34 & 1.10 & 0.10 & 0.36 & 0.45 & 0.07 & 0.38 & 0.07 & / & / & 93.83 & Coffinite (II) \\
\hline 8 & 12.12 & 46.71 & 0.25 & 1.53 & / & 0.18 & 1.06 & 0.73 & 16.51 & 0.49 & / & 0.31 & 0.12 & / & / & 80.01 & Ti-Coffinite (I) \\
\hline 9 & 0.37 & / & 0.11 & 0.12 & 0.03 & / & 0.10 & 0.23 & 97.61 & 1.28 & / & / & / & / & 0.08 & 99.93 & Anatase \\
\hline
\end{tabular}

\subsection{In Situ Sulfur Isotopic Composition}

Framboidal and cement pyrites are closely associated with altered ilmenite and the $U$ minerals present in the samples analyzed (Figure $3 e, f$ and Figure $5 b, d, f)$. The results of the in situ sulfur isotope analyses of the different types of pyrite are presented in Table 2 . The $\delta^{34} S$ values in framboidal pyrite range from $-9.9 \%$ to $-8.0 \%$ with an average value of $-9.04 \%$ (Yue et al., 2020). The $\delta^{34} S$ values of cement pyrite were higher, ranging between $+8.95 \%$ o to $+19.7 \%$, with an average value of $+15.80 \%$.

Table 2. In situ sulfur isotope analyses of different types of pyrite by LA-MC-ICP-MS in sandstonehosted U deposits in northern Ordos Basin.

\begin{tabular}{|c|c|c|c|c|}
\hline Type of Pyrite & Sample No. & $\delta^{34} S(\%)$ & Error(E-05) & Data Sources \\
\hline \multirow{5}{*}{$\begin{array}{c}\text { Framboidal } \\
\text { pyrite }\end{array}$} & EB01 & -9.60 & 1.15 & \multirow{8}{*}{ [44] } \\
\hline & EB06 & -9.90 & 1.39 & \\
\hline & EB06 & -8.00 & 1.41 & \\
\hline & EB06 & -8.50 & 1.37 & \\
\hline & EB14 & -9.20 & 0.98 & \\
\hline \multirow{10}{*}{ Cement pyrite } & EB16 & 18.20 & 0.41 & \\
\hline & EB18 & 19.70 & 0.42 & \\
\hline & EB18 & 18.60 & 0.41 & \\
\hline & B1-01 & 18.17 & 0.36 & \multirow{7}{*}{ This paper } \\
\hline & B1-02 & 8.95 & 0.09 & \\
\hline & B1-03 & 11.43 & 0.12 & \\
\hline & B1-04 & 10.73 & 0.14 & \\
\hline & B1-05 & 16.33 & 0.14 & \\
\hline & B1-06 & 18.74 & 0.33 & \\
\hline & B1-07 & 17.17 & 0.12 & \\
\hline
\end{tabular}




\section{Discussion}

\subsection{Pyrite Genesis and Ilmenite Alteration Process}

The $\delta^{34} S$ values and topographic characteristics of pyrite are commonly used to distinguish the genesis of pyrite. It is generally agreed that sulfate-reducing bacteria produce isotopically light reduced sulfur, whereas thermal sulfate reduction processes result in comparatively isotopic heavy sulfur [45-48]. The sulfur isotopic compositions of different types of pyrite show a large variation in $\delta^{34} S$ values, ranging from $-9.9 \%$ o to $-8.0 \%$, and from $+8.95 \%$ o to $+19.7 \%$, indicating that pyrite may have multiple origins. The $\delta^{34} S$ values of framboidal pyrite are negative and relatively homogeneous, indicating that it is potentially the product of sulfate-reducing bacteria (SRB), and the sulfur in framboidal pyrite is likely from the sediments $[44,46,47]$. Moreover, framboidal pyrite is generally considered to be produced in the synsedimentary $[48,49]$ or early diagenetic stages [50]. Therefore, it is concluded that the framboidal pyrite is the product of sulfate-reducing bacteria (SRB is defined above) in the synsedimentary or early diagenesis stages. The $\delta^{34} S$ values in cement pyrites ranging from $+8.95 \%$ o to $+19.7 \%$ are consistent with previous studies in which the $\delta^{34} S$ values of cement pyrites related to low-temperature thermal fluids range from $+15.7 \%$ o to $+21.2 \%$ [ [44]. This would suggest that the cement pyrites present are also related to low-temperature thermal fluids [51,52]. Moreover, a large number of studies identify a thermal event in the Ordos Basin during the Early Cretaceous through studies utilizing vitrine reflectance [28,31] and apatite fission-track dating [29,32]. Based on fluid inclusions homogenization temperatures $[17,20,53]$, alteration (carbonation, silicification, etc.) and mineral assemblages (anatase, pyrite, chalcopyrite, galenite, sphalerite, etc.) [17,34,38], a low-temperature thermal fluid was also invoked to have been associated with diagenesis and deposition of $U$ mineralization. Therefore, it is reasonable to believe that the cement pyrites are the product of thermal sulfate reduction (TSR) and the sulfur of these reactions probably comes from the natural gases produced by the deep Upper Paleozoic coal-measure source rocks migrated together with the low-temperature thermal fluid [44,45].

Based on above study on the genesis of different types of pyrites closely related to altered ilmenite, combined with the spatial relationship between framboidal pyrite, cement pyrite and altered ilmenite, the formation time series of ilmenite alteration products and $U$ minerals is clarified (Figure 6), and it is believed that the ilmenite alteration process can be divided into two stages. The first stage occurred in the early sedimentary diagenesis. Organic matter in host sandstone can react with $\mathrm{SO}_{4}{ }^{2-}$ in sediments to produce $\mathrm{H}_{2} \mathrm{~S}$ under the action of anaerobic sulfate-reducing bacteria. When ilmenite interacts with $\mathrm{H}_{2} \mathrm{~S}$, it can alter into porous leucoxene and framboidal pyrite (Equation (1)). The second stage occurred during the thermal tectonic event which led to the subsequent simultaneous migration of natural gas and the low-temperature thermal fluid. Ilmenite or partially altered ilmenite can form anatase and cement pyrite reacting with $\mathrm{H}_{2} \mathrm{~S}$ produced by thermal sulfate Equations (2) and (3). The characteristics of cement pyrite around altered ilmenite and framboidal pyrite are formed.

$$
\begin{gathered}
\mathrm{FeTiO}_{3}+\mathrm{H}_{2} \mathrm{~S}(\mathrm{BSR}) \rightarrow \mathrm{FeS}_{2} \text { (framboidal pyrite) }+\mathrm{TiO}_{2} \text { (leucoxene) }+\mathrm{H}_{2} \mathrm{O} \\
\mathrm{FeTiO}_{3}+\mathrm{H}_{2} \mathrm{~S}(\mathrm{TSR}) \rightarrow \mathrm{FeS}_{2} \text { (cement pyrite) }+\mathrm{TiO}_{2} \text { (anatase) }+\mathrm{H}_{2} \mathrm{O}
\end{gathered}
$$

$(\mathrm{Fe}) \mathrm{TiO}_{2}$ (partially altered ilmenite) $+\mathrm{H}_{2} \mathrm{~S}(\mathrm{TSR}) \rightarrow \mathrm{FeS}_{2}$ (cement pyrite) $+\mathrm{TiO}_{2}$ (anatase) $+\mathrm{H}^{+}$ 


\begin{tabular}{|c|c|c|c|}
\hline $\begin{array}{l}\text { Evolution stage } \\
\text { and time of } \\
\text { ore-bearing bed }\end{array}$ & $\begin{array}{c}\text { Synsedimentary and } \\
\text { early diagenesis stage } \\
\text { (Middle Jurassic) }\end{array}$ & $\begin{array}{c}\text { Thermal event } \\
\text { (Early Cretaceous) }\end{array}$ & $\begin{array}{c}\text { Continued uplift } \\
\text { (Late Cretaceous-Eocene })\end{array}$ \\
\hline Porous leucoxene & $\longrightarrow$ & & \\
\hline Framboidal pyrite & $=$ & & \\
\hline $\begin{array}{c}\text { Uraniferous } \\
\text { Leucoxene ( I ) }\end{array}$ & & & \\
\hline Anatase & & $=$ & \\
\hline Cement pyrite & & & $=$ \\
\hline Coffinite (II) & & & \\
\hline $\begin{array}{l}\text { Natural gas } \\
\text { dissipation }\end{array}$ & & & \\
\hline $\begin{array}{c}\text { Ilmenite alteration } \\
\text { process }\end{array}$ & The first stage & \multicolumn{2}{|c|}{ The second stage } \\
\hline $\begin{array}{l}\text { U enrichment process } \\
\text { of altered ilmenite }\end{array}$ & $\begin{array}{c}\text { U pre-enrichment with } \\
\mathrm{TiO}_{2} \text { adsorption }\end{array}$ & & $\begin{array}{l}\text { U enrichment with } \\
\mathrm{TiO}_{2} \text { catalytic reduction }\end{array}$ \\
\hline
\end{tabular}

Figure 6. Formation time series of ilmenite alteration products and $U$ minerals.

\subsection{U Enrichment Mechanism of Altered Ilmenite}

Various studies propose that altered ilmenite plays an important role in $\mathrm{U}$ enrichment through adsorption [7-14]. Due to its adsorptive behavior towards $\mathrm{U}, \mathrm{TiO}_{2}$ is widely used in extracting $U$ from seawater [54-56] and treatment of U-containing wastewater [57-62]. It is considered that $\mathrm{U}$ enrichment by $\mathrm{TiO}_{2}$ is mainly caused by physical and chemical adsorption (complexation and ion exchange), as observed through experimental studies [58-62] and relativistic DFT calculation [57]. The $\mathrm{pH}$ has a great influence on the adsorptive capacity of $\mathrm{TiO}_{2}$, and the adsorption amount of $U$ is the largest at weak acid environment [59-62]. In the Nalinggou $U$ deposit, leucoxene, the alteration product of ilmenite, is formed in the early sedimentary diagenesis with a weak acid environment and is often porous (Figures 3d,e, 4a and 5), which shows that it has strong adsorption capacity and can enrich $\mathrm{U}$ through adsorption. However, $\mathrm{U}$ minerals produced around altered ilmenite in the Nalinggou $U$ deposit indicates that the precipitation and enrichment of $U$ is not only the result of adsorption of altered ilmenite proposed by some scholars, but also related to reduction.

Recently, the $\mathrm{TiO}_{2}$ photocatalytic reduction of uranyl ions has been studied experimentally, providing a potential method of photocatalytic reduction for $U$ enrichment of altered ilmenite [63-65]. $\mathrm{TiO}_{2}$ can produce a light electron-hole pair that resides under the light excitation energy $(\mathrm{Eg}>3.14 \mathrm{eV})$. The light electron-hole pair can reduce $\mathrm{U}^{6+}$ to $\mathrm{U}^{4+}$ and form $\mathrm{U}$ minerals that may deposit on the surface of $\mathrm{TiO}_{2}$ (anatase) (Figure 7). For example, the experiment of photocatalytic reduction of uranyl ions by anatase $\left(\mathrm{TiO}_{2}\right)$ under light conditions carried out by Zhang [54] showed that it could reduce $\mathrm{U}^{6+}$ to $\mathrm{U}^{4+}$ in U-containing wastewater through adsorption-photocatalytic reduction in a short time, and the efficiency could reach $99.0 \%$, of which the adsorption rate of $\mathrm{TiO}_{2}$ could reach $20 \%$. However, for sandstone-hosted $U$ deposits, the mineralization process took place at the subsurface, lacking light to trigger the $\mathrm{TiO}_{2}$ photocatalytic reaction. 


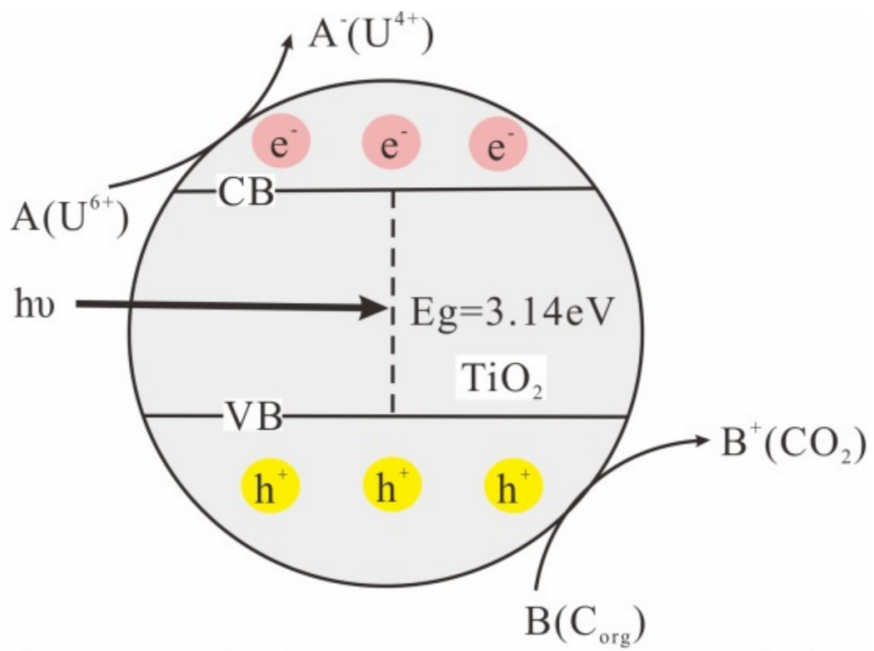

hv: light energy; Eg: band gap energy characteristics;

VB:valence band; $\mathrm{CB}$ : conduct band;

$\mathrm{e}^{\mathrm{e}}$ : photogenerated electron; $\mathrm{h}^{+}$: photogenerated hole

Figure 7. The mechanism of $\mathrm{TiO}_{2}$ photocatalytic reduction of uranyl ions (modified after [54]).

Wang [66] experimentally demonstrated that the $\mathrm{TiO}_{2}$ catalytic reduction via $\beta$ radiation under the absence of light could function. This mechanism demonstrates a route through which $\mathrm{TiO}_{2}$ can trigger a catalytic reduction reaction in an environment where there is no light, pending the presence of $\beta$-radiation. Most sandstone-hosted $U$ deposits have $U$ pre-enrichment in synsedimentary or early diagenesis stages [34,35,38-41]. A large amount of $\beta$ and $\gamma$ radiation would be produced during decay processes in these environments, providing the energy source for the catalytic reduction of $U$ by altered ilmenite.

Based on the above analysis, it is suggested that $U$ enrichment can be achieved by catalytic reduction as well as adsorption of altered ilmenite over geological timeframes. The presence of adsorbed $U$ is very important, which provides the $\beta, \gamma$ radiation and energy for the later catalytic reduction process. It provides a new mechanism by which sandstone-hosted U deposits may be enriched.

\subsection{U Enrichment Process of Altered Ilmenite}

Based on the characteristics of ilmenite alteration and its relationship with $U$ minerals, the $U$ enrichment process of altered ilmenite in sandstone-hosted $U$ deposits of the northern Ordos Basin can be divided into two stages, as follows (Figure 8).

$\mathrm{U}$ pre-enrichment with $\mathrm{TiO}_{2}$ adsorption (stage I): occurred during synsedimentary and early diagenesis stages. Ilmenite was altered into porous leucoxene and framboidal pyrite directly by $\mathrm{H}_{2} \mathrm{~S}$ of sulfate-reducing bacteria. The porous leucoxene can adsorb $\mathrm{U}^{6+}$ to form uraniferous leucoxene (I) in a weak acid environment, which was probably converted to Ticoffinite (I) with $\mathrm{U}^{6+}$ reduced to $\mathrm{U}^{4+}$ by reactions with reducing substances, corresponding to the $U$ pre-enrichment stage of sandstone-type $U$ deposits in the northern Ordos Basin. At the same time, mineral assemblage sequences of ilmenite, leucoxene, uraniferous leucoxene or Ti-coffinite (I) can be generated during partial alteration of ilmenite, and leucoxene, uraniferous leucoxene or Ti-coffinite (I) under conditions of complete alteration.

$\mathrm{U}$ enrichment with $\mathrm{TiO}_{2}$ (leucoxene and anatase) catalytic reduction (stage II) occurred during the uplift of the ore-bearing bed of sandstone-type $U$ deposits to the surface in the Late Cretaceous period, allowing the ore-forming fluid (U-O-bearing atmospheric) to infiltrate into the interlayer. The pre-enriched $U$ can decay and produce $\beta$ and $\gamma$ radiation over geological timeframes, triggering the formation of electron-hole pairs in leucoxene [66]. Electrons migrating to the surface of leucoxene can reduce $\mathrm{U}^{6+}$ in ore-forming fluid to $\mathrm{U}^{4+}$, and deposit on the surface of altered ilmenite in the form of coffinite (II), corresponding the paleo-interlayer oxidation stage of sandstone-type $\mathrm{U}$ deposits in the northern Ordos Basin. 
This will generate mineral assemblage sequences of leucoxene, Ti-coffinite (I), coffinite (II). In addition, some unaltered or weakly altered ilmenite can be altered into leucoxene and cement pyrite by $\mathrm{H}_{2} \mathrm{~S}$ of thermochemical sulfate reduction at the Early Cretaceous before the paleo-interlayer oxidation stage. Preformed cement pyrite and $\mathrm{H}_{2} \mathrm{~S}$ of the thermochemical sulfate reduction can reduce $\mathrm{U}^{6+}$ in ore-forming fluid to $\mathrm{U}^{4+}$ depositing on its surface in the form of coffinite (II), with the $\mathrm{S}^{2-}$ of pyrite oxidized to $\mathrm{SO}_{4}{ }^{2-}$ in the absence of oxygen $[67,68]$, and mineral assemblage sequences of leucoxene, Ti-coffinite (I), cement pyrite, and coffinite (II) can be formed.

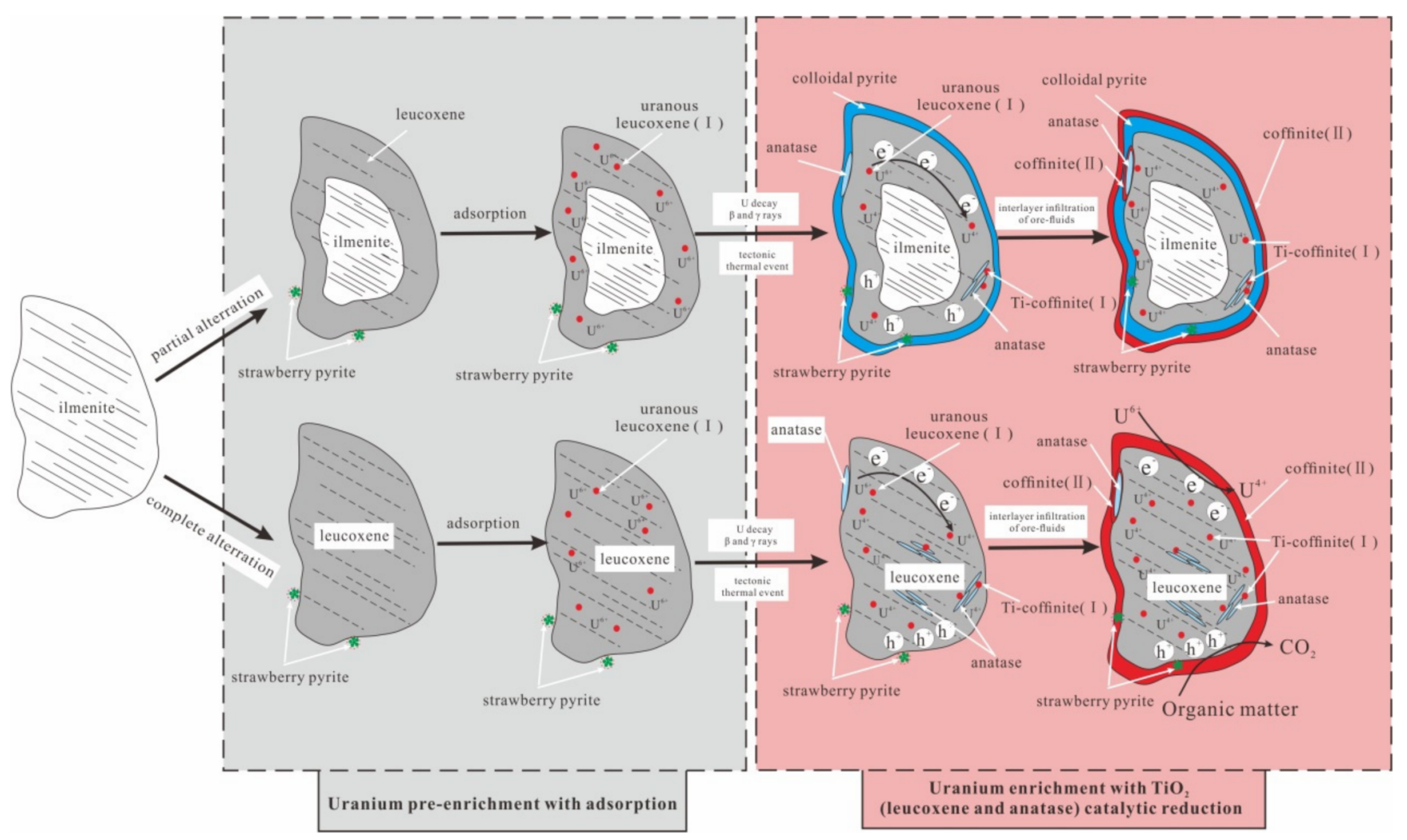

Figure 8. $U$ enrichment mechanism and alteration processes of ilmenite in sandstone-hosted $U$ deposits in the northern Ordos Basin.

\section{Conclusions}

(1) Ilmenite was prevalent in ore-bearing sandstone and was either completely or partially altered to porous leucoxene and anatase along the rim and crack. Framboidal pyrite of BSR origin and cement pyrite of TSR origin can be identified around altered ilmenite.

(2) Coffinite is the dominant $U$ mineral in sandstone-hosted U deposits of the northern Ordos Basin. Some of them produced in the pores and crack of altered ilmenite and are closely related to leucoxene and anatase in the form of burrs and needles; others are produced around altered ilmenite or cement pyrite. Two phases of U minerals closely related to altered ilmenite contain Ti-coffinite (I) and coffinite (II), indicating that $\mathrm{U}$ mineralization may take place through two stages.

(3) U enrichment can occur through adsorption and catalytic reduction of altered ilmenite. The enrichment process includes $U$ pre-enrichment via adsorption (stage I) and $\mathrm{TiO}_{2}$ (leucoxene and anatase) catalytic reduction (stage II). Pre-enriched U can decay and produce $\beta$ and $\gamma$ radiation, and can trigger the catalytic reduction reaction of leucoxene and anatase to reduce $\mathrm{U}^{6+}$ into $\mathrm{U}^{4+}$. This provides a new pathway to enrich $\mathrm{U}$ in sandstone-hosted U deposits. 
Author Contributions: Conceptualization, B.D. and H.-X.L.; Sample, B.D. and L.-F.Q.; methodology, B.D., L.-F.Q. and C.Z.; software, B.D., H.-X.L. and C.Z.; formal analysis, B.D.; investigation, B.D., L.-F.Q. and H.-X.L.; writing—original draft preparation, B.D., H.-X.L. and D.-R.X.; writing—review and editing, B.D., H.-X.L., C.Z. and D.-R.X.; supervision, H.-X.L. All authors have read and agreed to the published version of the manuscript.

Funding: This study was jointly funded by the Fourth Talent Project from China National Nuclear Corporation (No. QNYC2103), Opened-end Fund of State Key Laboratory Breeding of Nuclear Resource and Environment, East China University of Technology (No. NRE1908), BRIUG Youth Science and technology innovation fund (No. QJ2001) and Ministry of Science and Technology (No. 2015CB453004).

Data Availability Statement: No new data were created in this study. Data sharing is not applicable to this article.

Acknowledgments: The authors thank geology party No. 208 of CNNC for providing the ore samples and many useful data. We would also like to thank the anonymous reviews for their constructive comments and suggestions on the manuscript.

Conflicts of Interest: The authors declare no conflict of interest.

\section{References}

1. Reynolds, R.L.; Goldhaber, M.B. Iron-titanium oxide minerals and associated alteration phases in some uranium-Bearing sandstones. U.S. Geol. Surv. J. Res. 1978, 6, 707-714.

2. Reynolds, R.L.; Goldhaber, M.B. Origin of a South Texas roll-type uranium deposit: Alteration of iron-titanium oxide minerals. Econ. Geol. 1978, 73, 1677-1689. [CrossRef]

3. Reynolds, R.L. Post-deposidonal alteration of titanomagnetite in a Miocene sandstone, south Texas (U.S.A.). Earth Planet. Sci. 1982, 61, 381-391. [CrossRef]

4. Reynolds, R.L.; Goldhaber, M.B. Iron disulfide minerals and the genesis of roll-type uranium deposits. Econ. Geol. 1983, 78, 105-120. [CrossRef]

5. Reynolds, R.L.; Fishman, N.S.; Scott, J.H.; Hudson, M.R. Iron-titanium oxide minerals and magnetic susceptibility anomalies in the Mariano: Lake-Lake valley cores: Constraints on the conditions of uranium mineralization in the Morrison Formation, San Juan basin, New Mexico. Am. Assoc. Pet. Geol. Bull. 1986, 22, 303-314.

6. Fishman, N.S.; Turner-Peterson, C.E.; Reynolds, R.L. Alteration of magnetite and ilmenite in the Upper Jurassic Morrison Formation, San Juan basin, New Mexico: Relationship to facies and primary uranium mineralization. Am. Assoc. Pet. Geol. Bull. 1984, 68, 937.

7. Pointer, C.M.; Ashworth, J.R.; Simpson, P.R. Genesis of coffinite and the U-Ti association in Lower Old Red Sandstone sediments, Ousdale, Caithness, Scotland. Miner. Depos. 1989, 24, 117-123. [CrossRef]

8. Perelman, A.I. Hydrogenic Uranium Deposits; Atomizdat: Moscow, Russia, 1980. (In Russian)

9. Maksimova, M.F.; Shmariovich, E.M. Plastovoinfil'tratsionnoe rudoobrazovanie (Stratal-Infiltrational Ore Formation); Nedra: Moscow, Russia, 1993. (In Russian)

10. Bonnetti, C.; Liu, X.D.; Yan, Z.B. Coupled uranium mineralisation and bacterial sulphate reduction for the genesis of the Baxingtu sandstone-hosted U deposit, SW Songliao Basin, NE China. Ore Geol. Rev. 2017, 82, 108-129. [CrossRef]

11. Wei, J.L.; Tang, C.; Jin, R.S. A study of the relationship between the Fe-Ti oxide and sandstone-hosted uranium mineralization in Longhupao area, northern Songliao Basin. Acta Petrol. et Mineral 2019, 38, 375-389. (In Chinese with English Abstract)

12. Bonnetti, C.; Cuney, M.; Michels, R. The multiple roles of sulfate-reducing bacteria and Fe-Ti oxides in the genesis of the Bayinwula roll front-type uranium deposit, Erlian Basin, NE China. Econ. Geol. 2015, 110, 1059-1081. [CrossRef]

13. Wang, G.; Wang, Q.; Miao, A.S. Characteristic of uranium minerals in Nalinggou uranium deposit of Ordos Basin and their formation mechanism. Acta Mineral Sinaca 2017, 37, 461-469. (In Chinese with English abstract)

14. Chen, L.L.; Chen, Y.; Guo, H. Alteration characteristics of titanium-bearing minerals and new knowlrim about their relationship to uranium occurrence in uraniferous sandstone of Nalinggou area, Ordos Basin. Geol. China 2017, 45, 408-409. (In Chinese with English Abstract)

15. Ding, B.; Liu, H.X.; Zhang, B. Study on ilmenite alteration and its process of uranium enrichment in sandstone-type uranium deposits in northern Ordos Basin. Geol. Rev. 2020, 66, 467-473. (In Chinese with English Abstract)

16. Ding, B.; Liu, H.X.; Wang, W.Q. Material and method for treatment of U-containing wastewater based on U enrichment mechanism of altered ilmenite in Sandstone-type U deposit. At. Energy Sci. Technol. 2021, 55, 23-29. (In Chinese with English Abstract)

17. Xiao, X.J.; Li, Z.Y.; Fang, X.H. The Evidences and Significances of Epithermal Mineralization Fluid in the Dongsheng Sandstone Type Uranium Deposit. Bull. Mineral Petrol. Geochem. 2004, 23, 301-303. (In Chinese with English Abstract)

18. Fang, X.H.; Li, Z.Y. Research on coffinite in Dongsheng uranium field. Uranium Geol. 2017, 33, 257-265. (In Chinese with English Abstract) 
19. Wei, Y.; Wang, Y. Comparison of enrichment patterns of various energy and mineral resources in the Ordos Basin. Oil Gas Geol. 2004, 25, 385-392. (In Chinese with English Abstract)

20. Xue, C.J.; Chi, G.X.; Xue, W. Effects of hydrocarbon generation on fluid flow in the Ordos Basin and its relationship to uranium mineralization. Geosci. Front. 2011, 2, 439-447. [CrossRef]

21. Feng, Z.B.; Nie, F.J.; Deng, H.Z. Spatial-temporal collocation and genetic relationship among uranium, coal, and hydrocarbons and its significance for uranium prospecting:A case from the Mesozoic-Cenozoic uraniferous basins, North China. Russ. Geol. Geophys. 2017, 58, 611-623. [CrossRef]

22. Yang, X.Y.; Ling, M.X.; Sun, W.D. The genesis of sandstone type uranium deposits in the Ordos Basin, NW China: Constraints provided by fluid inclusions and stable isotopes. Int. Geol. Rev. 2009, 51, 422-455. [CrossRef]

23. Zhao, B.; Zhang, C.H.; Wang, D.Z. Contemporary kinematics of the Ordos block, North China and its adjacent rift systems constrained by dense GPS observations. J. Asian Earth Sci. 2017, 135, 257-267. [CrossRef]

24. Goldfarb, R.J.; Mao, J.W.; Qiu, K.F. The great Yanshanian metallogenic event of eastern Asia: Consequences from one hundred million years of plate margin geodynamics. Gondwana Res. 2021, 100, 223-250. [CrossRef]

25. Liu, C.; Zhao, H.; Gui, X. Space-time coordinate of the evolution and reformation andmineralization response in Ordos Basin. Acta Geol. Sin. 2006, 80, 617-638. (In Chinese with English Abstract)

26. Ritts, B.D.; Weislogel, A.; Graham, S.A. Mesozoic tectonics and sedimentation of the giant polyphase nonmarine intraplate Ordos Basin, western North China Block. Int. Geol. Rev. 2009, 51, 95-115. [CrossRef]

27. Deng, J.; Wang, Q.F.; Gao, B.F. Evolution of the Ordos Basin and its distribution of various energy and mineral resources. Geoscience 2005, 19, 538-545. (In Chinese with English Abstract)

28. Yuan, Y.S.; Hu, S.B.; Wang, H.J. Meso-Cenozoic tectonothermal evolution of Ordos basin, Central China: Insights from newly acquired vitrinite reflectance data and a revision of existing paleothermal indicator data. J. Geodyn. 2007, 44, 33-46. [CrossRef]

29. Ren, Z.L. Thermal history of the Ordos basin assessed by apatite fission track analysis. Acta Geophys. Sin. 1995, 38, 339-349.

30. Zhao, M.W. Application of AFT to the reconstruction of subsidence and uplift in the Ordos basin, China. Acta Geophys. Sin. 1996, 39, 238-248.

31. Zhao, M.W.; Behr, H.J. Vitrinite reflectance in Triassic with relation to geothermal history of Ordos basin, China. Acta Petrol. Sin. 1996, 17, 16-23.

32. Liu, W.S.; Qin, M.K.; Qi, F.C. Analysis on the Meso-Neozoic subsidence and uplift history of the periphery of Ordos basin using apatite fission track. Uranium Geol. 2008, 24, 221-232. (In Chinese with English Abstract)

33. Zhou, H.P.; Zhang, K.; Li, G. Cretaceous tectono-thermal event in the Ordos block: An Ar-Ar chronological evidence from basalt at Hangjinqi Banner, Inner Mongolia, North China Craton. Geotecton. et Metallog. 2008, 32, 360-364. (In Chinese with English Abstract)

34. Yi, C.; Wang, G.; Li, X.D. A tentative discussion on uranium enrichment characteristics and metallogenic model in Zhiluo Formation, northeastern Ordos Basin. Miner. Depos. 2018, 37, 835-852. (In Chinese with English Abstract)

35. Ding, B.; Liu, H.X.; Zhang, B. The formation mechanism of tabular orebody of sandstone-type uranium in northern Ordos basin: Constraints on the study of kaolinite content from different zones of ore-bearing sandstone. Acta Geol. Sin. 2020, 94, 2874-2882. (In Chinese with English Abstract)

36. Li, W.L.; Ji, W.M.; Liu, Z. Control of Boerjianghaizi Fault on Gas Accumulation of Upper Paleozoic in Northern Ordos Basin. Geoscience 2015, 29, 584-591. (In Chinese with English Abstract)

37. Zhang, G.X.; Miao, A.S.; Li, W.H. The Role of Boerjianghaizi faults in sandstone-type uranium mineralization. J. East China Univ. Technol. 2016, 39, 15-22. (In Chinese with English Abstract)

38. Li, Z.Y.; Fang, X.H.; Chen, P.A. Superposition metallogenic model of sandstone-type uranium deposit in the Northeastern Ordos basin. Uranium Geol. 2009, 25, 65-70. (In Chinese with English Abstract)

39. Zhang, C.; Yi, C.; Dong, Q. Geological and geochronological evidence for the effect of Paleogene and Miocene uplift of the Northern Ordos Basin on the formation of the Dongsheng uranium district, China. J. Geodyn. 2018, 114, 1-18. [CrossRef]

40. Xia, Y.L.; Lin, J.R.; Liu, H.B. Research on geochronology of sandstone-hosted uranium ore-formation major uranium productive basins, northern China. Uranium Geol. 2003, 19, 129-136. (In Chinese with English Abstract)

41. Liu, H.B.; Xia, Y.L.; Tian, S.F. Study on geochronology and uranium source of sandstone type uranium deposit in Dongsheng area. Uranium Geol. 2007, 23, 23-29. (In Chinese with English Abstract)

42. Coplen, T.B.; Bohlke, J.K.; De Bievre, P. Isotope-abundance variations of selected elements (IUPAC Technical Report). Pure App. Chem. 2002, 74, 1987-2017.

43. Johnston, D.T. Multiple sulfur isotopes and the evolution of Earth's surface sulfur cycle. Earth Sci. Rev. 2011, 106, 161-183. [CrossRef]

44. Yue, L.; Jiao, Y.; Wu, L.; Rong, H.; Fayek, M.; Xie, H. Evolution and origins of pyrite in sandstone-type uranium deposits, northern Ordos Basin, north-central China, based on micromorphological and compositional analysis. Ore Geol. Rev. 2020, 118, 103334 [CrossRef]

45. Xue, C.J.; Chi, G.X.; Fayek, M. Micro-textures and in situ sulfur isotopic analysis of spheroidaland zonal in the giant Jinding $\mathrm{Zn}-\mathrm{Pb}$ deposit, Yunnan, China: Implications for biogenic processes. J. Asian Earth Sci. 2015, 103, 288-304. [CrossRef]

46. Schwarcz, H.P.; Burnie, S.W. Influence of sedimentary environments on sulfur isotope ratios in clastic rocks: A review. Miner. Deposita. 1973, 8, 264-277. [CrossRef] 
47. Zhao, J.; Liang, J.L.; Long, X.P. Genesis and evolution of framboidal pyrite and its implications for the ore forming process of Carlin-style gold deposits, southwestern China. Ore Geol. Rev. 2017, 102, 426-436. [CrossRef]

48. Skei, J.M. Formation of framboidal iron sulfide in the water of a permanently anoxic fjord-Framvaren, South Norway. Chemistry 1988, 23, 345-352. [CrossRef]

49. Jiang, Y.F.; Qian, H.D.; Zhou, G.Q. Mineralogy and geochemistry of different morphological pyrite in Late Permian coals, South China. Arab. J. Geosci. 2016, 9, 590-607. [CrossRef]

50. Taylor, K.G.; Macquaker, J.H.S. Early diagenetic pyrite morphology in a mudstone-dominated succession: The Lower Jurassic Cleveland Ironstone Formation, eastern England. Sediment. Geol. 2000, 131, 77-86. [CrossRef]

51. Qiu, K.F.; Yu, H.C.; Deng, J. The giant Zaozigou Au-Sb deposit in West Qinling, China: Magmatic-or metamorphic-hydrothermal origin. Miner. Depos. 2020, 55, 345-362. [CrossRef]

52. Qiu, K.F.; Yu, H.C.; Hetherington, C.; Huang, Y.-Q.; Yang, T.; Deng, J. Tourmaline composition and boron isotope signature as a tracer of magmatic-hydrothermal processes. Am. Mineral. 2021, 106, 1033-1044. [CrossRef]

53. Zhang, L.; Liu, C.Y.; Zhao, Z.P. Fluid evolution and mineralization of Hangjinqi sandstone-type uranium deposit, Ordos basin. Earth Front. 2015, 22, 369-381. (In Chinese with English Abstract)

54. Zhang, L.H. Photocatalytic Reduction of Uranyl Ions over Nanostructured $\mathrm{TiO}_{2}$. Supervisor: Liu, Y.B. Master's Thesis, University of South China, Hengyang, China, 2013.

55. Mao, W.J. and Liu Z.R. Reaearch progress on absorbent materials for recovery uranium from seawater. Hydrometall. China 2014, 33, 247-251. (In Chinese with English Abstract)

56. Gupta, A.R. and Venkataramani B. Sorption of uranyl ions on hydrous: A new surface hydrolysis model. Bull Chem. Soc. Jpn. 1988, 61, 1357-1362. [CrossRef]

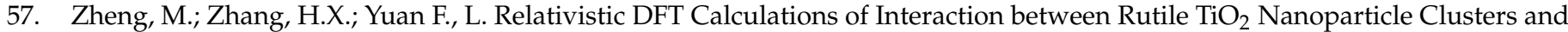
Uranyl Species. Chin. J. Inorg. Chem. 2018, 34, 874-882. (In Chinese with English Abstract)

58. Wang, J.; Wang, Y.; Wang, W. Visible light driven $\mathrm{Ti}^{3+}$ self-doped $\mathrm{TiO}_{2}$ for adsorption-photocatalysis of aqueous U (VI). Environ Pollut. 2020, 262, 114373. [CrossRef] [PubMed]

59. Zhang, W.; Ye, G.; Chen, J. Composite Materials for Uranium Adsorption. Prog. Chem. 2012, 24, 2330-2341. (In Chinese with English Abstract)

60. Zhang, Y.Y.; Lu, J.W.; Deng, C.Y. Adsorption Kinetics and Thermodynamics of Uranium(VI) by Humic Acid Titanium Salt. J. Univ. South China (Sci. Technol.) 2019, 33, 21-27. (In Chinese with English Abstract)

61. Wang, H.; Zheng Z., Y.; Dai, Y.H. Adsorption of U(VI) from aqueous solution using prepared flower-like nano TiO 2 . Hydrometall. China 2020, 39, 524-530. (In Chinese with English Abstract)

62. Zhang, H.Y.; Cao, J.Y.; Wang, Z.Y. Synthesis of $\mathrm{TiO}_{2}$ /SFP material and its uranium adsorption properties. J. Nucl. Radiochem. 2019, 41, 208-216. (In Chinese with English Abstract)

63. Amadelli, R.; Maldotti, A.; Sostero, S. Photodeposition of uranium oxides onto $\mathrm{TiO}_{2}$ from aqueous uranyl solutions. J. Chem. Soc. Faraday Trans. 1991, 87, 3267-3273. [CrossRef]

64. Latta, E.D.; Pearce, I.C.; Rosso, M.K. Reaction of $\mathrm{U}^{6+}$ with Titanium-substituted magnetite: Influence of Ti on $\mathrm{U}^{4+}$ speciation. Environ. Sci. Technol. 2013, 47, 4121-4130. [CrossRef] [PubMed]

65. Gong, X.; Tang, L.; Zou, J. Introduction of Cation Vacancies and Iron Doping into $\mathrm{TiO}_{2}$ Enabling Efficient uranium Photoreduction. J. Hazard. Mater. 2021, 423, 126935. [CrossRef] [PubMed]

66. Wang, L.Y. Investigation on the Catalytic Performance of $\mathrm{TiO}_{2}$ by $\beta$ Radioactivity and Nobel Metals. Supervisor: Liu, X.D Master's Thesis, East China University of Technology, Nanchang, China, 2018. (In Chinese with English Abstract).

67. Ding, B.; Liu, H.X.; Zhang, B. Mineralogical and isotopes evidence for origin of pyrite: Implication for formation mechanism of pyrite and its relationship with uranium mineralization in Mengqigu'er uranium deposit, Yili Basin. Miner. Depssits 2019, 38 , 1379-1391.

68. Ding, B.; Liu, H.X.; Zhang, C.; Liu, H.; Li, P.; Zhang, B. Mineralogy, Fluid Inclusion and H-O-C-S Stable Isotopes of Mengqiguer Uranium Deposit in the Southern Yili Basin, Xinjiang: Implication for Ore Formation. Acta Geol. Sin. (English Ed.). 2020, 94 1488-1503. [CrossRef] 